\title{
In Memoriam: Colin A. Palmer (1944-2019)
}

A lthough he had been suffering poor health for some time, Colin A. Palmer died unexpectedly on June 20 while on a research visit to his native Jamaica. A scholar of singular distinction, Palmer made an indelible impact on the historical profession. He was an outstanding teacher, a consummate academician, and a warm, thoughtful, kind, and gentle individual. He was 75 years old.

Palmer was born in the southwestern parish of Westmoreland in the county of Cornwall in Jamaica to a family of teachers, civil servants, postal officers, and politicians. A relative, Sir Clifford Campbell, was appointed the first locally born Governor General of the island of Jamaica after its independence in 1962.

He attended high school at Clarendon College, and went on to the University College of the West Indies (then an external College of the University of London), graduating in 1964 with a history honors degree. He entered the University of Wisconsin at Madison in January 1965 and enrolled in the newly established Comparative Tropical History Program, which would eventually become the foundation for the university's outstanding Global Studies program. Palmer majored in Latin American studies and persuaded the program director to accept his new minor in African Diaspora studies. He would eventually make extraordinary field-defining contributions to three distinct fields: Latin American, African Diaspora, and Caribbean history.

Palmer began his teaching career at Oakland University in Detroit, Michigan, and quickly rose through the ranks. In the course of his academic career, Colin held three endowed professorships in three different universities. He was appointed the William Rand Kenan Jr. Professor of History at the University of North Carolina at Chapel Hill, a position he held from 1986 to 1991. Between 1994 and 2000, he served as Distinguished Professor of History at the City University of New York, where he succeeded Arthur Schlesinger Jr. He was Dodge Professor of History at Princeton University between 2000 and his retirement in 2011. His protégés are legion. 
Palmer, not surprisingly, won numerous awards and fellowships. He was a fellow of the National Endowment for the Humanities, the Rockefeller Foundation, Oakland University, Wayne State University, the National Humanities Center, the Center for Advanced Study in the Behavioral Sciences, and the Stanford Humanities Center, as well as holding this eminent status at the University of the West Indies. In 2012, he was awarded the Carter G. Woodson Scholars Medallion by the Association for the Study of African American Life and Culture for his outstanding contribution to scholarship in the area Peoples of African Descent. In 2018, the University of North Carolina at Chapel Hill conferred on Palmer its award for scholarly distinction.

Palmer published 18 books, including pathbreaking monographs, insightful general studies, and the extensively consulted six-volume Encyclopedia of African American Culture and History. In addition, he published dozens of insightful articles in academic journals, along with many individual chapters and forewords in several outstanding books. His monographs are noted for their exceptionally extensive and impeccable archival research. Palmer enjoyed doing archival research and he never used research assistants. His original and highly nuanced interpretations of various themes invariably provided a broader, more integrated context than the scholarship before him.

His first book, Slawes of the White God: Blacks in Mexico, 1570-1650 (1976), reinvigorated investigations into the role of enslaved Africans in the history of early Spanish America. He constantly probed the meaning of "African Diaspora" for its similarities and differences across time, geographical space, and changing circumstances, as evidenced in such notable publications as The First Passage: Blacks in the Americas, 1502-1617 (1995), The African Diaspora (1996), and Passageways: An Interpretive History of Black America (1998). Moreover, Palmer insisted that the Diaspora could not be isolated from the histories of the original sending and receiving societies. He is the only scholar to publish a trilogy of outstanding monographs on the impact of British imperialism in three different Caribbean societies: Trinidad, Guyana, and Jamaica. His book Eric Williams and the Making of the Modern Caribbean (2006) provides an excellent analysis of the intellectual profile and political life of Eric Williams, the long-serving prime minister of Trinidad. Cheddi Jagan and the Politics of Power: British Guiana's Struggle for Independence (2010) exposed the cynical conspiracy by the British Colonial Office and the Central Intelligence Agency of the United States of America to undermine democracy in that British colony on the South American mainland. Freedom's Children: The 1938 Labor Rebellion and the Birth of Modern Jamaica (2014) and Inward Yearnings: Jamaica's Journey to Nationhood (2016) go beyond narratives of 
political genesis to provide incisive analyses of the conflicted quest for collective identity in Jamaica during the middle decades of the twentieth century.

Colin Palmer was more than just another outstanding academic. He was a conscientious activist in the good, old-fashioned sense of the word. In Michigan he wrote speeches for Mayor Coleman Young of Detroit. In North Carolina he served as chair of the board of directors of the National Humanities Center. He sat on the research committee of the American Historical Association. Colin was also recognized as a superb administrator. At the University of North Carolina at Chapel Hill he simultaneously chaired the African and Afro-American Studies Department (1980-88) and the History Department (1986-91). Between 2000 and 2012, while at the City University of New York Graduate Center and Princeton University, he directed the Scholars-in-Residence Program of the Schomburg Center for Research in Black Culture of the New York Public Library. He was instrumental in the creation of the Department of African American Studies at Princeton University. In May 2018, he was invited to deliver the keynote address at the 80th anniversary of the founding of the People's National Party in Kingston, Jamaica.

Colin Palmer leaves a powerful legacy of excellent professional writing as well as a superb example of effective teaching and research.

Johns Hopkins University

FRANKLIN W. KNIGHT

Baltimore, Maryland

fknight1@jhu.edu 